\title{
Impact of Spiritual Greenery Activities
}

\author{
Yangdon
}

Lecturer, Samtse College of Education, Royal University of Bhutan, Bhutan

\begin{abstract}
The Green School for Green Bhutan programme was implemented across all schools in Bhutan in 2010. This programme constitutes eight dimensions: environmental greenery, academic greenery, intellectual greenery, social greenery, spiritual greenery, cultural greenery, aesthetic greenery, and moral greenery. All schools across the country practise meditation and mind training/mindfulness as part of spiritual greenery activities. Additional spiritual greenery activities such as choesed leyram (religious discourse) annual rimdro (ritual), and green day are also implemented. Although spiritual greenery activities have been implemented in schools since 2010, not much is known about their impact due to limited literature. Using a qualitative design, data for the study were gathered from 28 participants from six school in Samtse district, Bhutan using a semi-structured interview. Thematic analysis was used for data analysis. The findings from the study showed that the implementation of spiritual greenery activities has positively impacted for both teachers and students.
\end{abstract}

Keywords - Eight dimensions, green school, impact, spiritual greenery.

\section{INTRODUCTION}

The overall framework for development programmes used in Bhutan is termed 'Gross National Happiness' (GNH) which seeks to strike a balance between material and nonmaterial components of development (Planning Commission, 1999). Bhutan's national vision for education is to promote the development of "an educated and enlightened society of Gyalyong Gakid Pelzom [Gross National Happiness], at peace with itself, at peace with the world, built and sustained by the idealism and the creative enterprise of our citizens" (MoE, 2013, p. v). The Ministry of Education (MoE) in Bhutan, in its endeavour to promote $\mathrm{GNH}$, launched a nationwide initiative termed Educating for Gross National Happiness (EGNH) in 2010 (Tshomo, 2016). EGNH is promoted and supported by the Green School for Green Bhutan programme, which comprises eight dimensions: environmental greenery, academic greenery, intellectual greenery, moral greenery, aesthetic greenery, social greenery, cultural greenery, and spiritual greenery. Following the initiation of the Green School for Green Bhutan programme in 2010, schools across the country started meditation and mindfulness as spiritual greenery activities. Other spiritual greenery activities such as choesed leyram, annual rimdro, and green day were also implemented in the schools. However, little is known about the impact of spiritual greenery activities due to limited research and literature. Thus far, only two studies have explored the Green School for Green Bhutan programme. One study by Drakpa and Dorji (2013) investigated the contribution of the Green School for Green Bhutan programme towards the realisation of Gross National Happiness in 13 schools in Chukha district and another study by Gayphel, Jose, Yangdon, Giri, Sonam, and Dorji (2014) explored principals', teachers', and students' perceptions of green school and one of its dimensions, spiritual greenery. These two studies have not examined the impact of spiritual greenery activities. The present study explored the impact of spiritual greenery activities. Being the first study on the impact of spiritual greenery activities, the study will contribute to the body of literature and knowledge on spiritual greenery. The findings of this study are anticipated to provide an empirical base for policy advice concerning the implementation and impact of spiritual greenery activities to the Ministry of Education, policy makers, curriculum designers, educationists, and teacher educators.

\section{LITERATURE REVIEW}

\section{Spirituality in Education}

The meaning of spirituality in education has been explored and highlighted from different perspectives by many authors. Spirituality in education is primarily concerned with wholeness, connectedness or relationship with oneself, with others, with nature, or with the world (Astin, 2004; Eaude, 2005; Hay \& Nye, 2006; Jones, 2005; Palmer, 1999), child-centered pedagogy (Watson, 2014), nurturing holistic development (Crawford \& Rossiter, 2006; Roux, 2006; Taggart, 2001), inviting students to encounter their inner lives and the interior lives of others in 
a more profound and caring way (Kessler, 1999), and helping students embrace humility, respect, compassion, and gentleness (Dei, 2002; Jackson \& Monteux, 2003). For others, spirituality in education refers to "a sense of awe, wonder, mystery, a search for meaning and purpose, feelings and emotions, self-knowledge and beliefs - these beliefs need not necessarily be related to a religious belief system" (O'Brien, 1998, p. 47) and "no more-and no lessthan a deep connection between student, teacher, and subject-a connection so honest, vital, and vibrant that it cannot help but be intensely relevant" (Jones, 2005, p. 2). According to Jones (2005), the nourishment of spirituality "in the classroom allows it to flourish in the world, in the arenas of politics, medicine, engineering-wherever our students go after graduation" (p. 2).

In Bhutan, spiritual greenery is synonymous with spirituality in education in other countries. According to Powdyel (2014), spiritual greenery is:

An acceptance of the need for support from higher beings-ideals, objects, signs, gods, goddesses, spiritual figures, power of nature, our root lam ${ }^{1}$, including our parents and teachers who inspire and empower us. It is the condition of our inner life that accepts and honours the divine in us and that links us to the divine higher than us. It has nothing to do with any religion or dogma but could be allied to emotional intelligence. (pp. 45-46)

Powdyel further claims that:

Modern education, sadly, has no room for such an orientation. That is the reason that today's scholars become experts in their fields of specialization but are bereft of the saving graces of the spiritual elements that enrich us and empower us. (Personal communication, October $6,2016)$

In summary, spirituality in education is concerned with nurturing holistic development of students to establish connections with self, others, and the world. Nurturing spiritual development in pupils is advocated to be an essential component of education.

\section{Importance of spirituality in education}

Children's spiritual development is increasingly being advanced as an important aspect of their well-being. Malviya (2011), for example, claims that "an awareness of the important role of spirituality is growing within the education system...students are seeking for personal

\footnotetext{
${ }^{1}$ Abbot
}

identity to give meaning to their lives in the fast-paced world of the 21st century" (p. 52). Mainstream schools around the world are now actively implementing programmes that recognise the importance of nurturing a child's social, emotional, mental, spiritual, and cognitive well-being (Tregenza, 2009; Yager, 2009). Spirituality is identified as an important component of school curricula in New Zealand and England. The New Zealand curriculum mandates that teachers cater to the spiritual well-being of the students (MoE, 1996). Similarly, the Office for Standards in Education (Ofsted, 2004) in England and Wales recommends spiritual development of children and young people to be a significant focus in all lessons. However, Noddings (1992) comments, "The more I think about the centrality of spirituality in our lives, the more concerned I become about its shameful neglect in the public undertaking we call 'education'. Surely our responsibility to educate includes attention to matters of spirit" (p. 85).

In Bhutan, spiritual greenery is one of the dimensions in promoting a Green School towards a Green Bhutan. Moreover, Jackson and Monteux (2003) state:

The right to spiritual well-being is firmly embedded in the 1989 UN Convention on the Rights of the Child. A clear duty is placed on all relevant bodies to ensure that a child's spiritual well-being is nurtured along with his or her physical and intellectual well-being. All carers have an ethical responsibility to recognize and respond to spirituality as it is presented within all human beings and they must be equipped to recognize, understand and deal with this dimension. (pp. 52-53)

Additionally, Powdyel claims:

Spiritual greenery is a call to pay attention to the myriad of infinite powers that lie beyond our limited personal realms. If one recognises the sources of these positive powers and lives one's life in harmony with them, our life and experiences become that much fuller and that much more fulfilling. (Personal communication, 6 October, 2016)

Overall, spirituality is widely recognised as being an essential component of education.

\section{Nurturing children's spiritual development}

Eaude (2005) claims that young children's spiritual development will be lost if it is not intentionally nurtured. Proponents of spirituality in education have suggested different ways of promoting spirituality in schools. 
Moriarty (2013) proposes that sport could be used to promote spirituality since it is a source of wonder, wellbeing, and connection and enhances learners' sense of selfworth. Furthermore, Davies (1988) contends that spirituality can be nurtured through all the subjects of the curriculum. This aim can be achieved by teachers engaging in reciprocal connections with students, providing handson activities, and allowing students freedom of expression and authentic wondering (Hyde, 2008; Palmer, 1999; Sewell, 2009). Correspondingly, Malviya (2011, p. 54) espouses that "teachers need to be courageous and deeply engaged in teaching students, bringing their entire selves, including their spirituality, to their teaching". Powdyel (2014, p. 46) asserts that "schools and institutions need to create many moments of silence and reflection for renewal, connection and for life". Families and community also have pivotal roles to play in the spiritual development of young people (Fisher, 2008). In summary, there is widespread support for the view that spiritual development in pupils can be nurtured through both curricular and extracurricular activities. In the Bhutanese education system, spiritual development is nurtured through spiritual greenery activities such as meditation and mindfulness practice, which are implemented across all schools in the country.

\section{Spiritual Greenery Activities - Meditation and Mindfulness}

Meditation and mindfulness are practised through schoolbased meditation and mindfulness programmes in some schools around the world. In Bhutan, meditation is one of the elements of GNH education that addresses the psychological well-being of students (MoE, 2015). Meditation is defined as a "process of paying attention, often to a particular object designated as the focus of concentration or object of meditation, which is commonly the breath or repetition of an inspirational word or phrase, referred to as a mantra" (Campion \& Rocco, 2009, p. 47) and "emptying of the mind of thoughts or the concentration of mind on one thing in order to aid mental or spiritual development, contemplation or relaxation" (MoE, 2015, p. 127). Meditative practices are now being integrated into schools to support social and emotional learning for students (Wisner, 2013).

Meditation, which is highlighted as a secular practice in Bhutanese schools, is intended to help students concentrate and discover their innate virtues and potential, teach them values of kindness (MoE, 2015), help them calm their minds, and improve memory power (MoE, 2012). In addition, Thinley (2010) states:
Just a few minutes of contemplation and meditation at the beginning and end of a school day or a ceremony, ritual, class, assembly, or even sports event can change and deepen the atmosphere on the spot and bring instant connection with the inner joy that is the essence of GNH. (para. 36)

Furthermore, Powdyel maintains:

To meditate and to be mindful are essential pathways to cultivating spiritual greenery. Even when children meditate, they should be guided to reflect on those uplifting and enriching objects and not simply to close their eyes and be done with meditation! (Personal communication, 6 October, 2016)

Studies have demonstrated that meditation programmes in schools help to increase calmness and relaxation and assist in emotional/behavioural control (Napoli, 2004; Wall, 2005), improve mood, cognitive functioning, and selfregulation (Grossman, Niemann, Schmidt, \& Walach, 2004), reduce stress and increase forgiveness (Oman, Shapiro, Thoresen, Plante, \& Flinders, 2008), decrease mental health problems, boost well-being and enhance academic achievement (Waters et al., 2015), enhance tolerance, sociability, empathy, positive thinking, and a positive state of mind (Beddoe \& Murphy, 2004; Chang et al., 2004; Lutz, Slagter, Dunne, \& Davidson, 2008), and increase positive feelings about the self, improve mood, increase peaceful feelings, reduce frustration and aggravation, enhance clarity of the mind, improve concentration and focus, provide better control of bad thoughts, increase positive thoughts, and promote a more relaxed mind (Wisner, 2013). Additional benefits for the whole school community include teachers and students being calmer, more relaxed, less stressed, and happier, resulting in a calmer, less stressed, and more relaxed school climate (Wisner, 2013).

Correspondingly, in a study conducted in Bhutan, some of the benefits of meditation on the students were found to include enhanced concentration and interest in the subjects, increased attachment to the school, reduced aggressiveness and anxieties, enhanced control of anger, improved behaviour, enhanced inner peace, and increased willingness to help others (Gayphel et al., 2014). The study also highlighted that the practice of meditation resulted in the principals and teachers becoming friendlier among themselves as well as with the students. Given the benefits of meditation, it is beginning to be viewed as an essential practice that transcends any religion (Ricard, 2006). 
The use of mindfulness in educational settings is also gaining momentum and significance. According to Kabat-Zinn (2003, p. 145), mindfulness is the "awareness that emerges through paying attention on purpose, in the present moment, and non-judgmentally to the unfolding of experience moment by moment". Along the same line, Thinley (2012) defines mindfulness as "gaining control of one's thoughts and emotions and learning to use one's mental energies to positive ends, which constitutes the essence of Educating for GNH" (p. 97). The purpose of mindfulness is to create a state of relaxed attention that enables individuals to achieve more flexibility in their psychological and physical responses to various situations (Greenberg \& Harris, 2012). The practice of mindfulness also helps "change our attitudes and values-changing our ways of behaviour that can help us to achieve GNH" (MoE, 2015, p. 127).

A number of programmes that incorporate mindfulness have been developed in some western countries to specifically harness teacher resilience, compassion, and habits of minds (Roeser, Skinner, Beers, \& Jennings, 2012), to establish children's well-being (Lillard, 2011), and to enhance both students' and teachers' well-being in the classroom (Greenberg \& Harris, 2012; Mendelson et al., 2010). Albrecht, Albrecht, and Cohen (2012) contend that stress in the school system is "stimulating the proliferation of wellness promoting programmes" (p. 1). They further report that depression is the most common youth problem encountered by youth aged 12-15 years in countries such as Australia (Albrecht et al., 2012). If depression and anxiety are left untreated, they become risk factors for alcohol and drug problems and may lead to suicidal thoughts and actions (McGorry, Purcell, Hickie, \& Jorm, 2007). Additionally, Rempel (2012) suggests, "children deserve to experience life positively and society has a duty to provide them with skills and strategies to manage life's more challenging moments. Mindfulness maybe one way to provide this" (p. 217).

There is a growing body of literature addressing the benefits of mindfulness practice for students and teachers. Research studies have indicated that mindfulness practice has: helped to reduce teachers' stress levels, depression and anxiety; assisted behaviour management strategies and improved self-esteem (Gold et al., 2010); improved optimism, social competence, self-concept, and emotional resilience (Schonert-Reichl, Kimberly, \& Lawlor, 2010); and developed inhibitory control (Oberle, Schonert-Reichl, Kimberly, Lawlor, \& Thomson, 2012). Similarly, other research studies have shown that mindfulness practice has: benefited the whole child (i.e., the mind, body, and emotions); improved academic performance, executive functioning, and feelings of connectedness with self and others; improved happiness (Ager et al., 2015); reduced reactivity; increased self-care, self-awareness, and a sense of connection with nature (Wall, 2005); improved behavioural regulation and metacognition (Flook et al., 2010); reduced levels of stress; and facilitated self-calming (Wisner, 2014). The practice of mindfulness has also been found to reduce depressive symptoms (Lau \& Hue, 2011) and lower internalising and externalising behaviours (Lee, Semple, Rosa, \& Miller, 2008). The benefits for teachers have been found to include increased mindfulness improved teaching self-efficacy, and improved physical health (Poulin, Mackenzie, Soloway, \& Karayolas, 2008)

The importance of teachers in influencing the behaviour of children and the youth of Bhutan has been recognised; therefore, mindfulness education has been introduced into the two colleges of education: Paro and Samtse. According to Thinley (2012), mindfulness education is about:

1. training to develop 'mindfulness' as a technique to investigate into one's own mind;

2. developing positive values which govern one's behaviour which determines one's happiness;

3. learning to be aware of one's thoughts and emotions and to check on one's behaviour; and

4. training one's mind to enhance its potential which is almost limitless. (p. 98)

He further reports that the two colleges of education in Samtse and Paro have been involved in "promoting mindfulness education ever since the Ministry of Education embarked on promoting it throughout the education system and supporting the most profound idea of Gross National Happiness" (Thinley, 2012, p. 98). For effective implementation of Educating for GNH in the school, "the Principal, Vice principal and teachers should practise meditation and mind training first and be convinced of the impact before they ask students to practise in the school" (MoE, 2015, p. 30). In sum, the implementation of meditation and mind training will be successful if taught by people who practice what they preach.

\section{METHODOLOGY}

Data for the study were gathered from 28 participants using semi-structured interviews. In-depth semi-structured interview data constitute the empirical backbone of much qualitative research in the social sciences (Campbell, Quincy, Osserman, \& Pedersen, 2013). Harvey-Jordan and Long (2001) contend that semi-structured interviews are 
used widely in qualitative research to understand why people act in particular ways by exploring participants' perceptions, experiences, and attitudes. A semi-structured interview was used rather than a structured interview as the former offers "sufficient flexibility to approach the respondents differently while still attending to the same areas of data collection" (Noor, 2008, p. 1604).

The participants were from three higher secondary schools and three lower secondary schools in Samtse district, Bhutan. In order to gain perspectives from both urban and semi-urban schools and from both genders, sampling ensured that there were participants from these school types and locations and included both males and females. A purposeful, criterion-based sampling strategy was employed to select the 28 participants. Criteria for selection included that the participants:

1. had at least two years of teaching experience, as that meant they would have some experiences of implementing spiritual greenery activities;

2. belonged to a school that had more than two participants, as it was considered impractical to visit a school to interview just one or two participants;

3. were willing to participate in the interview; and

4. could communicate in English quite well, as the interview was to be conducted in English.

All 28 participants were invited to participate in a semistructured interview through email. Consent for the interview and audio recording of the interview were sought and obtained from the participants and confidentiality and anonymity were assured. A verbatim transcription of both the questions and the responses provided by the interviewees was carried out. The transcripts were emailed to the participants for their comments and feedback. This member-checking process is essential to confirm the credibility of the information and narrative account (Creswell \& Miller, 2000). The data were analysed using thematic analysis. Thematic analysis is a commonly used technique in qualitative research. Thematic analysis is defined as a systematic approach to pattern recognition within the data, with emerging themes becoming categories for analysis (Braun \& Clarke, 2006; Fereday \& MuirCochrane, 2006). Namey, Guest, Thairu, and Johnson (2008) posit that thematic analysis "focuses on identifying and describing both implicit and explicit ideas" (p.138). NVivo was used for data management and analysis.

\section{RESULTS AND DISCUSSION}

The findings from the study showed that the implementation of spiritual greenery activities such as meditation, mindfulness training, choesed leyram, annual rimdro and green day has positively impacted both teachers and students. The impacts for the students included improvement in their behaviour, development of civics sense, enhanced memory and better retention of ideas, better concentration, less stressed, more relaxed and refreshed and being able to control their minds. Additional benefits included more controlled anger, increased attention span, improved cognitive development, improved participation in the class and inculcation of values of sharing enhancement of their social skills, creation of bond of togetherness between teacher and students and between students. Similarly, spiritual greenery activities have benefitted the teachers both personally and professionally. For example, spiritual greenery activities have helped them calm down, refresh, be at peace and be mentally and physically healthy and manage stress. Spiritual greenery activities such as meditation and mindfulness have also served as good attention gaining strategies especially in the lower classes. The conduct of meditation and mindfulness have made the classroom environment less chaotic and helped in the smooth conduct of the lessons. All these benefits have helped to improve individuals' lives and enabled teachers and students to live in harmony in the school. Similar benefits have been reported in the literature. For example, studies have demonstrated that meditation programmes in schools increase calmness and relaxation, assist in emotional/behavioural control (Napoli, 2004; Wall, 2005), improve mood, cognitive functioning, and self-regulation (Grossman, Niemann, Schmidt, \& Walach, 2004), reduce stress (Oman, Shapiro, Thoresen, Plante, \& Flinders, 2008), decrease mental health problems, boost well-being (Waters et al., 2015), enhance tolerance, sociability, empathy, positive thinking, and a positive state of mind (Beddoe \& Murphy, 2004; Chang et al., 2004; Lutz, Slagter, Dunne, \& Davidson, 2008), and increase positive feelings about the self, improve moods, increase peaceful feelings, reduce frustration and aggravation, help clear the mind, aid concentration and focus, allow for the control of bad thoughts, increase positive thoughts, and relax the mind (Wisner, 2013). Correspondingly, in a study conducted in Bhutan, some of the reported benefits of meditation on the students were enhanced concentration and interest in the subjects, increased attachment to the school, reduced aggressiveness and anxieties, more controlled anger, improved behaviour, enhanced inner peace, and improvement in their attitude to help others (Gayphel et al., 2014). 


\section{CONCLUSION}

The findings from the study showed that the implementation of spiritual greenery activities has positively impacted both teachers and students. These benefits ranged from improving the personal and academic lives of students to improving the personal and professional lives of the teachers. The empirical findings from the study are essential, as the evidence may assist the different stakeholders in supporting the implementation of spiritual greenery activities. In addition, policy mandates that schools advance spiritual greenery activities as one of the threads to help achieve the vision of Green School for Green Bhutan, EGNH, and GNH. However, the implementation and impact of spiritual greenery activities is challenged by lack of empirical evidence to guide the teachers and the school leaders. Hence, there is an urgent need for more research to be conducted on spiritual greenery activities in order to progress the cause of the Green School for Green Bhutan programme, EGNH, and GNH. The present study helps to (i) reduce the gap in the literature, and (ii) add to the body of literature and Knowledge on the impact of spiritual greenery activities both nationally and internationally.

\section{REFERENCES}

[1] Ager, K., Albrecht, N. J., \& Cohen, M. (2015). Mindfulness in schools research project: Exploring students' perspectives of mindfulness - What are students' perspectives of learning mindfulness practices at school? Psychology, 6(7), 896914.

[2] Albrecht, N., Albrecht, P., \& Cohen, M. (2012). Mindfully teaching in the classroom: A literature review. Australian Journal of Teacher Education, 37(12), 1-14.

[3] Astin, A. W. (2004). Why spirituality deserves a central place in liberal education. Liberal Education, 90(2), 34-41.

Beddoe, A. E., \& Murphy, S. O. (2004). Does mindfulness decrease stress and foster empathy among nursing students? Journal of Nursing Education, 43(7), 305-312.

[4] Braun, V., \& Clarke, V. (2006). Using thematic analysis in psychology. Qualitative Research in

Psychology, 3(2), 77-101. oi:10.1191/1478088706qp063oa

[5] Braun, V., \& Clark, V. (2012). Thematic analysis. In H. Cooper, P. M. Camic, D. L. Long, A. T.

Panter, D. Rindskopf, \& K. J. Sher (Eds.), APA handbook of research methods in psychology (pp. 57-71). Washington, DC: American Psychology Association.

[6] Campbell, J. L., Quincy, C., Osserman, J., \& Pedersen, O. K. (2013). Coding in-depth semi-structured interviews: Problems of unitization and intercoder reliability and agreement. Sociological Methods \& Research, 42(3), 294320 .
[7] Campion, J., \& Rocco, S. (2009). Minding the mind: The effects and potential of a school-based meditation programme for mental health promotion. Advances in School Mental Health Promotion, 2(1), 47-55. doi:10.1080/1754730X.2009.9715697

[8] Chang, V., Y., Palesh, O., Caldwell, R., Glasgow, N., Abramson, M., Luskin, F., Koopman, C. (2004). The effects of a mindfulness based stress reduction program on stress, mindfulness self-efficacy, and positive states of mind. Stress and Health, 20(3), 141-147. doi:10.1002/smi.1011

[9] Crawford, M., \& Rossiter, G. (2006). Reasons for living: Education and young people's search for meaning, identity and spirituality: A handbook. Camberwell, Victoria: ACER Press.

[10] Creswell, J. W., \& Miller, D., L. (2000). Determining validity in qualitative inquiry. Theory Into Practice, 39(3), 124-130. doi:10.1207/s15430421tip3903_2

[11] Davies, G. (1988). What is spiritual development? Primary headteachers' views. Holistic Medicine, 3(2), 123-134. doi:10.1080/1364436980030204

[12] Dei, G. J. S. (2002). Spiritual knowing and transformative learning: Essays on theory and praxis. In E. O'Sullivan, A. Morrell, \& M. A. O'Connor (Eds.), Expanding the boundaries of transformative learning (pp. 123-133). UK: Palgrave Macmillan.

[13] Drakpa, D., \& Dorji, R. (2013). Green School for Green Bhutan: Relationship with Gross National Happiness in Chukha dzongkhag. International Journal of Business Intelligence, 2, 314-324.

[14] Drupka, K., \& Brien, K. (2013). Educating for Gross National Happiness: A new paradigm for education in Bhutan. Antistasis, 3(2), 11-15.

[15] Eaude, T. (2005). Strangely familiar? Teachers making sense of young children's spiritual

development. Early Years, 25(3), 237-248. doi:10.1080/09575140500251764

[16] Fereday, J., \& Muir-Cochrane, E. (2006). Demonstrating rigor using thematic analysis: A hybrid approach of inductive and deductive coding and theme development. International Journal of Qualitative Methods, 5(1), 80-92.

[17] Fisher, J. W. (2008). Impacting teachers' and students' spiritual well-being. Journal of Beliefs \& Values, 29(3), 253261. doi:10.1080/13617670802465789

[18] Flook, L., Smalley, S., L., Kitil, M. J., Galla, B. M., KaiserGreenland, S., Locke, J., Kasari, C. (2010). Effects of mindful awareness practices on executive functions in elementary school children. Journal of Applied School Psychology, 26(1), 7095. doi:10.1080/15377900903379125

[19] Gayphel, K., Jose, K. C., Yangdon, Giri, N., Sonam, S., \& Dorji, U. (2014). Spiritual greenery in five schools of Samtse, Bhutan - An enquiry. Unpublished paper. 
[20] Gold, E., Smith, A., Hopper, I., Herne, D., Tansey, G., \& Hulland, C. (2010). Mindfulness-based stress reduction (MBSR) for primary school teachers. Journal of Child and Family Studies, 19(2), 184-189. doi:10.1007/s108260099344-0

[21] Greenberg, M. T., \& Harris, A. R. (2012). Nurturing mindfulness in children and youth: Current state of research. Child Development Perspectives, 6(2), 161-166. doi:10.1111/j.1750-8606.2011.00215.x

[22] Grossman, P., Niemann, L., Schmidt, S., \& Walach, H. (2004). Mindfulness-based stress reduction and health benefits: A meta-analysis. Journal of Psychosomatic Research, 57(1), 35-43.

[23] Harvey-Jordan, S., \& Long, S. (2001). The process and the pitfalls of semi-structured interviews. Community Practitioner, 74(6), 219-221.

[24] Hay, D., \& Nye, R. (2006). The spirit of the child. London: Jessica Kingsley Publishers.

[25] Hyde, B. (2008). The identification of four characteristics of children's spirituality in Australian Catholic primary schools. International Journal of Children's Spirituality, 13(2), 117-127. doi:10.1080/13644360801965925

[26] Jackson, R., \& Monteux, A. (2003). Promoting the spiritual well-being of children and young people with special needs. Scottish Journal of Residential Child Care, 2(1), 52-54.

[27] Jones, L. (2005). What does spirituality in education mean? Journal of College and Character, 6(7), 1-7. doi:10.2202/1940-1639.1485

[28] Kabat-Zinn, J. (2003). Mindfulness-based interventions in context: Past, present, and future. Clinical Psychology: Science and Practice, 10(2), 144-156.

[29] Kessler, R. (1999). Nourishing students in secular schools. Educational Leadership, 56(4), 49-52.

[30] Lau, N. S., \& Hue, M. T. (2011). Preliminary outcomes of a mindfulness-based programme for Hong Kong adolescents in schools: Well-being, stress and depressive symptoms. International Journal of Children's Spirituality, 16(4), 315330. doi:10.1080/1364436X.2011.639747

[31] Lee, J., Semple, R., J., Rosa, D., \& Miller, L. (2008). Mindfulness-based cognitive therapy for children: Results of a pilot study. Journal of Cognitive Psychotherapy, 22(1), 1528.

[32] Lillard, A. S. (2011). Mindfulness practices in education: Montessori's approach. Mindfulness, 2(2), 78-85. doi:10.1007/s12671-011-0045-6

[33] Lincoln, Y., S., \& Guba, E., G. (1985). Naturalistic inquiry. Beverly Hills, California: Sage Publications.

[34] Lutz, A., Slagter, H., A., Dunne, J., D., \& Davidson, R., J. (2008). Attention regulation and monitoring in meditation. Trends in Cognitive Sciences, 12(4), 163-169. doi:10.1016/j.tics.2008.01.005
[35] Malviya, V. (2011). Spirituality in education for holistic development. Review of Management, 1(1), 51-58.

[36] McGorry, P., D., Purcell, R., Hickie, I., B., \& Jorm, A., F. (2007). Investing in youth mental health is a best buy. Medical Journal of Australia, 187(7), 5-7.

[37] Mendelson, T., Greenberg, M. T., Dariotis, J. K., Gould, L. F., Rhoades, B. L., \& Leaf, P. J.(2010). Feasibility and preliminary outcomes of a school-based mindfulness intervention for urban youth. Journal of Abnormal Child Psychology, 38(7), 985-994. doi:10.1007/s10802-010-9418$\mathrm{x}$

[38] MoE. (1996). The New Zealand curriculum. Wellington, New Zealand: Learning Media.

[39] MoE. (2009). Educating for Gross National Happiness workshop. Thimphu: Ministry of Education.

[40] MoE. (2011). Educating for GNH: A guide to advancing Gross National Happiness. Thimphu: DCRD, Ministry of Education.

[41] MoE. (2012). 15th Annual Education Conference. Retrieved from

Http://www.education.gov.bt/documents/10180/317343/14th +AEC.pdf/b36e571 b-22b8-

48ed-b59f-e22046e19f1d?version=1.0

[42] MoE. (2013). The centenarian: 100 years of educating the nation. Thimphu: Ministry of Education.

[43] MoE. (2015). Educating for Gross National Happiness: A training manual. Thimphu: EMSSD, Ministry of Education.

[44] Moriarty, M. W. (2013). Sport and children's spirituality: An Australian perspective. International Journal of Children's Spirituality, 18(1), 103-117.

doi:10.1080/1364436X.2013.771116

[45] Namey, E., Guest, G., Thairu, L., \& Johnson, L. (2008). Data reduction techniques for large qualitative data sets. In G. Greg \& K. MacQueen (Eds.), Handbook for team-based qualitative research (pp. 137-159). Lanham, Maryland: AltaMira Press.

[46] Napoli, M. (2004). Mindfulness training for teachers: A pilot program. Complementary Health Practice Review, 9(1), 3142. doi:10.1177/1076167503253435

[47] Noddings, N. (1992). The challenge to care in schools: An alternative approach to education. New York: Teacher College Press.

[48] Noor, K. B. M. (2008). Case study: A strategic research methodology. American Journal of Applied Sciences, 5(11), 1602-1604.

[49] Oberle, E., Schonert-Reichl, Kimberly, A., Lawlor, M. S., \& Thomson, K. C. (2012). Mindfulness and inhibitory control in early adolescence. Journal of Early Adolescence, 32(4), 565-588. doi:10.1177/0272431611403741

[50] O'Brien, T. (1998). Promoting positive behaviour. London: David Fulton Publishers. 
[51] Ofsted. (2004). Promoting and evaluating pupils' spiritual, moral, social and cultural development. London: Her Majesty's Stationery Office.

[52] Oman, D., Shapiro, S., L., Thoresen, C., E., Plante, T., G., \& Flinders, T. (2008). Meditation lowers stress and supports forgiveness among college students: A randomized controlled trial. Journal of American College Health, 56(5), 569578. doi:10.3200/JACH.56.5.569-578

[53] Palmer, P. J. (1999). Evoking the spirit in public education. Educational Leadership, 56(4), 6-11.

[54] Planning Commission. (1999). Bhutan 2020: A vision for peace, prosperity and happiness (Part 1). Thimphu: Royal Government of Bhutan.

[55] Poulin, P. A., Mackenzie, C. S., Soloway, G., \& Karayolas, E. (2008). Mindfulness training as an

evidenced-based approach to reducing stress and promoting wellbeing among human services professionals. International Journal of Health Promotion and Education, 46(2), 72-80. doi:10.1080/14635240.2008.10708132

[56] Powdyel, T. S. (2013). Outlines of a GNH school: Some reflections. In MoE (Ed.), The centenarian: 100 years of educating the nation (pp. 48-53). Thimphu: Ministry of Education.

[57] Powdyel, T. S. (2014). My green school - An outline: Supporting the Educating for Gross National Happiness initiative. Thimphu: Kuensel Corporation Limited.

[58] Rempel, K. D. (2012). Mindfulness for children and youth: A review of the literature with an argument for school-based implementation. Canadian Journal of Counselling and Psychotherapy 46(3), 201-220.

[59] Ricard, M. (2006). Happiness: A guide to developing life's most important skill. New York: Little Brown and Company.

[60] Roeser, R. W., Skinner, E., Beers, J., \& Jennings, P. A. (2012). Mindfulness training and teachers' professional development: An emerging area of research and practice. Child Development Perspectives, 6(2), 167-173. doi:10.1111/j.17508606.2012.00238.x

[61] Roux, C. (2006). Children's spirituality in social context: A South African example. International Journal of Children's Spirituality $11(1)$

151-163. Doi:10.1080/13644360500504462

[62] Schonert-Reichl, Kimberly, A., \& Lawlor, M. S. (2010). The effects of a mindfulness based education program on pre-and early adolescents' well-being and social and emotional competence. Mindfulness, 1(3), 137-151. doi:10.1007/s12671010-0011-8

[63] Sewell, A. (2009). Evoking children's spirituality in the reciprocal relationships of a learning community. International Journal of Children's Spirituality, 14(1), 516. doi:10.1080/13644360802658685

[64] Taggart, G. (2001). Nurturing spirituality: A rationale for holistic education. International Journal of Children's
Spirituality, $\quad 6(3)$,

Doi:10.1080/13644360120100496

325-339.

[65] Thinley, P. (2012). Mindfulness education in the Royal University of Bhutan: Context, present status and future possibilities. Bhutan Journal of Research and Development, 1(1), 97-108.

[66] Tregenza, V. A. (2009). Looking back to the future: The current relevance of Maria Montessori's ideas about the spiritual well-being of young children. Journal of Student Well-being, 2(2), 1-15.

[67] Tshomo, P. (2016). Conditions of happiness: Bhutan's Educating for Gross National

Happiness initiative and the capability approach. In M. J. Schuelka \& T. W. Maxwell (Eds.), Education in Bhutan: Culture, schooling, and Gross National Happiness (pp. 139152). Singapore: Springer.

[68] Wall, R. B. (2005). Tai chi and mindfulness-based stress reduction in a Boston public middle school. Journal of Pediatric Health Care, 19(4), 230-237. doi:10.1016/j.pedhc.2005.02.006

indicators of GNH. Journal of Bhutan Studies, 26, 53-81.

[69] Waters, L., Barsky, A., Ridd, A., \& Allen, K. (2015). Contemplative education: A systematic, evidence-based review of the effect of meditation interventions in schools. Educational Psychology Review, 27(1), 103-134. doi:10.1007/s10648014-9258-2

[70] Watson, J. (2014). Editorial. International Journal of Children's Spirituality, 19(2), 6568. doi:10.1080/1364436X.2014.929770

[71] Wisner, B. L. (2013). Less stress, less drama, and experiencing monkey mind: Benefits and challenges of a school-based meditation program for adolescents. School Social Work Journal, 38(1), 49-63.

[72] Wisner, B. L. (2014). An exploratory study of mindfulness meditation for alternative school students: Perceived benefits for improving school climate and student functioning. Mindfulness, 5(6), 626-638.

[73] Yager, Z. (2009). Developing well-being in first year preservice teachers: Reflections on a personal approach to professional education. Journal of Student Well-being, 3(1), $52-72$. 